\title{
Development of Skill Assessment Instruments Based on Food Sanitation Hygiene Principles in Learning Food Processing Practices for Vocational Students Catering Services Expertise Program in Malang City
}

\author{
Teti Setiawati ${ }^{1}$, Lismi Animatul Chisbiyah ${ }^{2}$ \\ ${ }^{1,2}$ Department of Industrial Technology, Faculty of Engineering, Universitas Negeri Malang \\ *Corresponding author,Email: teti.setiawati.ft@um.ac.id
}

\begin{abstract}
This study aims to produce skills assessment instruments based on the principles of food sanitation hygiene in learning food processing practices for vocational students in Catering Services Expertise Program in Malang City. The research approach uses development research $(\mathrm{R}$ and $\mathrm{D})$ adapted from the procedure of developing Borg and Gall, without the last stage, namely dissemination and implementation. Data analysis uses quantitative and qualitative approaches. The development of the instruments produced is a hygiene principlebased learning evaluation instrument based on food processing practice learning. The results of the validation test from the expert validator and user validator indicate that the assessment instrument can be used by the teacher in conducting assessments to measure students' skills in implementing the principles of hygiene and food sanitation in learning food processing practices.
\end{abstract}

Keywords: assessment instruments, skills assessment, the principles of food hygiene

\section{INTRODUCTION}

Based on the 2013 curriculum, aspects of assessment are designed with the aim of strengthening student competency. On the other hand, behavior is a competency that must be achieved by students after participating in learning.

In the Curriculum of the Catering Services Expertise Vocational School, the subjects of Sanitation, Hygiene, and Work Safety in the Field of Food are theoretical subjects included in the Basic Specialization Program in the Expertise Program. Competencies that must be achieved by students include handling food to prevent the proliferation of microorganisms. The competencies achieved are expected to be implemented in every learning practice of food processing productive subjects. The aim is to instill habits in students so that hygiene behavior is formed in the organization of food and drinks, so that the food produced is safe for consumption. According to Government Regulation No. 28 of 2004, food security is the condition and effort needed to prevent food from the possibility of biological, chemical and other contaminants that disturb, harm and endanger human health. These hazards or contaminants are often found and found due to the low quality of raw materials, processing technology, inadequate implementation of adequate hygiene and sanitation practices and lack of awareness of food handlers.
Food handler is a person who is directly related to food, both at the time of preparation, processing, storage, and transportation, until the presentation stageThrough a food handler who pays little attention to food hygiene, the disease can spread to consumers or to people who consume the food they produce. Therefore, a food handler, must always be in a healthy condition, skilled, maintaining personal hygiene and accustomed to healthy behavior during work. According Kusmayadi (2007) there are 4 (four) important things that need to be considered a food handler which is the principle of food hygiene. These include: healthy and clean behavior of people who manage food, food hygiene, equipment hygiene and processing hygiene.

Vocational High Schools (SMK) especially the Catering Services Expertise Package, is one of the educational institutions that is responsible for creating food handlers. In order to produce graduates who have the knowledge, skills, and habits in applying the principles of food hygiene during the process of food processing and serving, the curriculum of the Food Service Expertise Package curriculum contains a number of education and training programs. One of the training courses related to food hygiene is Sanitation, Hygiene, and Work Safety subjects.

Postma Leonie, et al (2004) explained that some schools in several countries do not pay attention to hygiene and sanitation, even though hygiene and sanitation are very important and need to be included in the school 
curriculum. Curriculum according to Law No. 20 of 2003 concerning the National Education System is a set of plans and arrangements regarding the objectives, content and learning materials as well as the methods used to guide the implementation of learning activities to achieve certain educational goals. Given the importance of hygiene behavior, especially in food processing, hygiene and sanitation subjects must be in the curriculum, and need to be implemented in every learning processing practice.

Based on the results of surveys and observations of the Vocational High School Catering Services Package in Malang which implemented the 2013 curriculum (K 13), it is known that the learning tool in the form of a Learning Implementation Plan specifically for learning processing practices in productive subjects has not yet implemented Higeine's behavior in detail and operationally.

Referring to Minister of Education and Culture Regulation No. 65 of 2013 concerning Basic and Secondary Education Process Standards, stated that the preparation of learning tools is part of learning
planningLearning planning is designed in the form of syllabus and lesson plans that refer to content standards. In addition, in the planning of learning also carried out the preparation of learning materials and resources, and assessment instruments. Considering the importance of instilling hygiene attitudes and behaviors in students, as well as the results of preliminary studies, it is necessary to conduct development research aimed at developing assessment instruments. The assessment instrument developed was an instrument to measure students' hygiene behavior when learning food processing practices.

\section{RESEARCH METHODS}

The research approach used in this research is development research ( $\mathrm{R}$ and $\mathrm{D})$ adapted from development procedures, without the last stage, namely dissemination and implementation. Following are the steps to the research development method ( $\mathrm{R}$ and $\mathrm{D}$ ) Borg dan Gall (Borg, W.R.\& Gall,M.D. 1989).

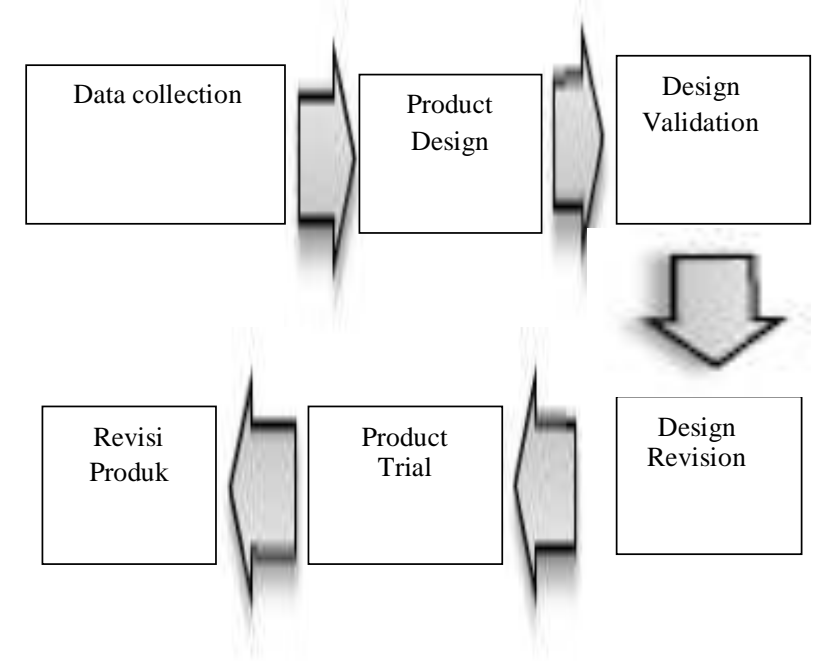

Figure 1. Research Steps

The first step is collecting data through preliminary research. The preliminary research was conducted by survey and interview with the teacher of food processing practice subjects. The purpose of the preliminary research is to determine the implementation of food hygiene and sanitation in learning food processing practices starting from the learning device in the form of a Learning Implementation Plan made by teachers. The results of preliminary research indicate the need to develop a Learning Implementation Plan for food processing practices that implements food hygiene and sanitation. One of the learning tools that is part of the lesson plan is the assessment instrument. The assessment instruments developed are instruments that are oriented towards assessing students' skills in implementing the principles of food hygiene and sanitation in learning processing practices.

The second stage is product design. The assessment instrument was designed through the following steps: 1) Identify all important steps that will affect the final result (output); 2) Write down and sort all aspects of specific abilities that are important to produce or finish the best outcome; 3) Aspects of the ability to be measured are not too many, so that all can be observed during student practice; 4) Clearly define all aspects of the ability to be measured. The ability to be measured must be observable (observable); 5) Check and compare all aspects of capabilities that have been made before if there is a comparison (Direktorat PSMK, 2015). The results of this stage are prototype I. 
Prototype 1 is generated, then validated at the design validation stage. Validity test is carried out by expert validators namely lecturers who are experts in learning evaluation, and teachers as material expert validators. Validation subjects were asked to rate the design. Validation subjects were asked to rate the design. The results of the design validation are used to revise the product.

The next stage is the design revision stage. The design was revised according to notes and input from expert validators. The results of the revision of the initial product (prototype I), hereinafter referred to as prototype II. At this stage, the validator is the practical lesson teacher as a user

The next stage is the prototype II trial phase. At this stage, the validator is the user of the practice of Indonesian Food Processing and Presentation in Vocational Schools throughout Malang (SMK Negeri 2,
SMK Negeri 3, SMK Negeri 7, SMK Kartika, and SMK Coryesu Malang).

The final stage is the revision stage, which is carried out based on input from the teachers as user validators

\section{III.DATA ANALYSIS TECHNIQUE}

This research uses a quantitative and qualitative analysis approach. Data analysis is used on the stages of research and development, namely: 1) data analysis at the preliminary study stage using qualitative analysis; 2) the development stage is analyzed quantitatively and qualitatively, and 3) data analysis of the results of development trials using quantitative analysis. Final evaluation criteria for quantitative data, calculated based on the results of the conversion of quantitative data to qualitative data with a scale of 5. Conversion of qualitative data is carried out based on the conversion formula shown in the following Table 3.1

Table 3.1 Value Conversion Score

\begin{tabular}{|c|c|c|}
\hline Score Interval & Score & Category \\
\hline $\mathbf{X}>\mathrm{Xi}+1,50 \mathrm{SDi}$ & 5 & Verry good \\
$<\mathbf{X} \leq \mathrm{Xi}+1,50 \mathrm{SDi}$ & 4 & Good Good enough \\
$<\mathbf{X} \leq \mathrm{Xi}+0,50 \mathrm{SDi}$ & 3 & Less \\
& & \\
$<\mathbf{X} \leq \mathrm{Xi}-0,50 \mathrm{SDi}$ & 2 & Verry Less \\
$\mathbf{X}<\mathrm{Xi}-1,50 \mathrm{SDi}$ & 1 & \\
\hline
\end{tabular}

Information:

$\mathrm{Xi}=$ Ideal average $=1 / 2($ ideal maximum score + ideal minimum score $)$

$\mathrm{Sdi}=$ Ideal standard deviation

$=1 / 6$ (ideal maximum score + ideal minimum score)

$\mathrm{X}=$ Skor aktual

Ideal maximum score $=5$

Ideal minimum score $=1$

$\mathrm{Xi} \quad=1 / 2(5+1)=3$

SDi $=1 / 6(5-1)=0,67$

Scale $5=X>3+(1,5 \times 0,67)$

$$
=X>3+1,01=X>4,01
$$

Scale $4=3+(0,50 \times 0,67)<X<4,01$

$$
\begin{aligned}
& =3+0,34<X<4,01 \\
& =3,34<X<4,01
\end{aligned}
$$

Scale $3=3-0,34<X<3,34$

$$
=2,26<X<3,34
$$

Scale $2=3-(1,5 \times 0,67)<X<2,26$

$$
=3-(1,01)<\mathrm{X}<2,26
$$

$$
=1,99<X<2,26
$$

Scale $1=X<1,99$

Based on the above calculation, the 5 scale quantitative data conversion is simplified as stated in Table 3.2 
Table 3.2 Quantitative Data Conversion Results

\begin{tabular}{|l|c|}
\hline Range & Category \\
\hline$X>4,01$ & Verry good \\
\hline $3,34<X<4,01$ & Good \\
\hline $2,26<X<3,34$ & Good enough \\
\hline $1,99<X<2,26$ & Less \\
\hline$X<1,99$ & Verry Less \\
\hline
\end{tabular}

\section{DEVELOPMENT RESULTS}

This development research results in a product in the form of an instrument of skills assessment in learning food processing practices in Indonesian Food Processing and Serving lessons. The following are the results of each stage of the development procedure carried out:

\section{PRELIMINARY STUDIES}

The results of preliminary studies through literature studies, surveys of vocational high schools in Malang, and the results of interviews with teachers who teach food processing practices, obtained information that so far the teachers in implementing learning food processing practices especially the subject of Indonesian Food Processing and Serving, more oriented to products that prioritize performance such as taste, texture, aroma and garnish. Attention to aspects of food hygiene and sanitation that is expected to produce products that are safe for consumptiononly done globally without applying the principles of food sanitation in a coherent way from the procurement of materials to serving food.

The principles of food sanitation hygiene in learning processing practices, are not explicit and detailed in the lesson plan. Therefore, its implementation in learning received less attentionThus, this study was designed and developed in reference to the application of food sanitation hygiene principles to food processing practices. The assessment instruments are part of the lesson plan, therefore to measure the success of learning objectives that have been formulated in the lesson plan, then it is necessary to design and develop an assessment instrument as a measurement tool.

\section{Product Design}

The assessment instruments developed in this study were skills assessment instruments consisting of assessment rubrics and scoring criteria. The product design development stage is carried out through the following steps:

1. Determine the skills assessment instruments and instruments to be developed. The skills assessment technique developed is the assessment of processes and products that refer to the application of food hygiene and sanitation before, during and after processing.

2. Instrument Formulation / Writing

The formulation / writing of the assessment instrument starts from determining the instrument specifications including determining the measurement objectives, lattices, shapes, instrument format, and instrument length. Next it is presented in the form of a skills assessment instrument that contains statements of each specified indicator.

3. Compile assessment rubrics

The assessment rubric is arranged based on the stages in implementing food hygiene and sanitation in learning food processing practices.

\section{Design Validation}

The validation of learning evaluation experts to the learning evaluation tools developed in this study include:

1) The score used in the evaluation is $0-100$, not $1-5$.

2) It should also be assessed aspects of hygiene behavior such as "washing hands before and after work, also before and after toilet training", It should also be assessed aspects of hygiene behavior such as "washing hands before and after work, also before and after toilet trainning", and also added to evaluate the condition of the equipment for processing, serving equipment, and distribution used. Tools that comply with the principles of food hygiene and sanitation are tools that are not cracked or chipped.

3) The scoring guide rubric should be arranged in more detail.

4) Aspects of assessment in the rubric guidelines for personal hygiene assessment, there are several aspects that should be put together. For example: hand and nail hygiene, just hand hygiene; nasal hygiene, and ears together with bodily hygiene.

5) In the scoring rubric there is no formula for the results obtained. Recap of validation results from the expert evaluation of learning at the development stage is presented in Table 3.3 
Table 3.3 Average Score of Validation Instrument Assessment Results by Learning Evaluation Experts

\begin{tabular}{|l|l|c|}
\hline No & \multicolumn{1}{|c|}{$\begin{array}{c}\text { Quality Criteria for Valuation } \\
\text { Instruments }\end{array}$} & Average Score \\
\hline 1 & $\begin{array}{l}\text { Appropriateness of assessment } \\
\text { instruments with learning objectives }\end{array}$ & 4 \\
\hline 2 & $\begin{array}{l}\text { Suitability of assessment instruments } \\
\text { with subject matter }\end{array}$ & 4 \\
\hline 3 & Coverage of assessment instruments & 3 \\
\hline 4 & Scoring guidelines rubric & 3.75 \\
\hline
\end{tabular}

Table 3.3 above shows that the results of calculating the average score of the learning evaluation expert on the learning evaluation tools developed obtained a value of 3.75This means that the learning evaluation tool for Indonesian Food Processing and Serving subjects developed is in the good category.

The data above also shows the results of the design validation of the construction aspects, the product is declared good, meaning that there is consistency between parts of the instrument. The part is between objectives, material, and assessment instruments. In addition, the substance was also declared to be very good, meaning that there was a match between the objectives, material and assessment instruments.

Furthermore, although the results of the analysis indicate that the product is valid, but based on input submitted qualitatively, the assessment instrument was revised according to the suggestions and comments of the expert validators. Then the validation test is conducted by the teacher as the user. The teacher who is a user validator is a vocational school teacher specializing in food service expertise in Malang, who teaches Indonesian Food Processing and Servicing courses in the eleventh grade of the first semester. Then the validation test is conducted by the teacher as the user.

The teacher who is a user validator is a vocational school teacher specializing in food service expertise in Malang,

Table 3.4 User Validity Test Results

\begin{tabular}{|l|l|c|}
\hline No & Quality Criteria for Learning Implementation Plan & Average Score \\
\hline 1 & $\begin{array}{l}\text { Appropriateness of assessment instruments with } \\
\text { learning objectives }\end{array}$ & 4,6 \\
\hline 2 & $\begin{array}{l}\text { Suitability of assessment instruments with subject } \\
\text { matter }\end{array}$ & 4,3 \\
\hline 3 & Coverage of assessment instruments & 4,2 \\
\hline 4 & Scoring guidelines rubric & 4,5 \\
\hline \multicolumn{2}{|c|}{ Average Score } & 4.4 \\
\hline
\end{tabular}

Table 3.4 above shows that in general the average score of the assessment instrument, a score of 4.4 (very good) was obtained. As for the review of each shows that the suitability between the assessment instruments with learning objectives obtained a score of 4.6 (very good); The average score about the suitability of the assessment instruments with the subject matter is 4.3 (very good); who teaches Indonesian Food Processing and Servicing courses in the eleventh grade of the first semester. Then the validation test is conducted by the teacher as the user. The teacher who is a user validator is a vocational school teacher specializing in food service expertise in Malang, who teaches Indonesian Food Processing and Servicing courses in the eleventh grade of the first semester. Then the validation test is conducted by the teacher as the user. The teacher who is a user validator is a vocational school teacher specializing in food service expertise in Malang, who teaches Indonesian Food Processing and Servicing courses in the eleventh grade of the first semester. Then the validation test is conducted by the teacher as the user. The teacher who is a user validator is a vocational school teacher specializing in food service expertise in Malang, who teaches Indonesian Food Processing and Servicing courses in the eleventh grade of the first semester. Then the validation test is conducted by the teacher as the user. The teacher who is a user validator is a vocational school teacher specializing in food service expertise in Malang, who teaches Indonesian Food Processing and Servicing courses in the eleventh grade of the first semester. The validation results from the user teacher, obtained the results as set out in Table 3.4.
The average score on the coverage of the assessment instruments is 4.2 (very good); and the average score on the scoring guidelines rubric is 4.5 (very good).

Thus, the assessment instrument developed in this study was declared valid or feasible to be used as an evaluation tool in learning. 
giving a fair assessment of students. Teachers do not need to memorize students one by one, so the assessment can be more subjective. The weakness of the product of this development is not yet tested its effectiveness, because it has not been tested

\section{CONCLUSIONS AND SUGGESTIONS}

Based on the explanation above, it can be concluded that the skills assessment instrument developed, is feasible to be used to implement the principles of food hygiene and sanitation in learning food processing practices.

Related to the weaknesses that are found, then the suggestions or recommendations submitted are necessary to do a product trial to find out its effectiveness.

\section{REFERENCES}

[1] Borg, W.R.\& Gall,M.D. 1989. Educational Research and Introduction. New York \& London: Longman.

[2] Krathwohl David R. 2002. A Revision of Bloom's Taxonomy: An Overview. College of Education, The Ohio State University

[3] Kunandar. 2013. Penilaian Autentik (Penilaian Hasil Belajar Peserta Didik berdasarkan Kurikulum 2013). Jakarta: PT. Raja Grafindo Persada.

[4] Minister of Education and Culture Regulation No. 65 of 2013 concerning Basic and Secondary Education Process Standards

[5] Postma, Leonie; Getkate, Renate and van Wijk, Christine.2004. Life Skills-Based Hygiene Education: A guidance document on concepts, development and experiences with life skillsbased hygiene education in school sanitation and hygiene education programmes. Delft, The Netherlands, IRC International Water and Sanitation Centre. (Technical Paper Series; no. 42).

[6] Republic of Indonesia Government Regulation No.28 of 2004. Concerning Food Safety, Quality and Nutrition (Statute Book No. 107/2004, Supplement to Statute Book Number 4424)

[7] UU no. 20 Th 2003 concerning National Education System

[8] UU No. 20 Th 2003 concerning the National Education System

[9] Undang-Undang No.7. Tahun 1996 Concerning Food (Statute Book Year 1996 Number 99, Supplement to Statute Book Number 3656).

\section{Strengths and Weaknesses of Development Products}

This development product has strengths and weaknesses. As reviewed above, the advantage of this skill assessment instrument is that it is equipped with an assessment scale that teachers can rely on to measure student skills during learning. Therefore, the results of measurements using this development instrument will further assist teachers in 